\title{
Porto-arterial plasma concentration differences of urea and ammonia-nitrogen in growing pigs given high- and low-fibre diets
}

\author{
BY KJELL MALMLÖF \\ Department of Animal Nutrition and Management, Swedish University of Agricultural \\ Sciences, S-750 07 Uppsala, Sweden
}

(Received 9 April 1986 - Accepted 9 January 1987)

1. The effects of a high- (HF) and a low- (LF) fibre diet on porto-arterial plasma concentration differences and plasma levels of urea and ammonia-nitrogen were compared in six Swedish Landrace $\times$ Yorkshire pigs $(30-52 \mathrm{~kg})$. Portal and arterial blood samples were drawn during $8 \mathrm{~h}$ following two consecutive meals, given at 08.00 and 16.00 hours.

2. The HF diet, in comparison with the LF diet, was found to produce significantly lower portal plasma urea levels. However, concomitant arterial plasma levels were equally depressed, consequently leaving the porto-arterial urea differences unchanged.

3. In no instance during the $16 \mathrm{~h}$ studied could negative porto-arterial urea differences clearly be observed. It was thus concluded that none of the diets induced an important net flux of plasma urea directly from the circulation into the gastrointestinal tract.

4. The significantly lower circulating plasma urea levels that were observed when the pigs received the HF diet were also associated with significantly lower urinary excretions of urea.

5. The HF and LF diets had similar effects on portal and arterial plasma levels of ammonia-N. This was also true with regard to porto-arterial ammonia- $\mathrm{N}$ differences.

It is well established that in some non-ruminant species a high-fibre diet increases the faecal nitrogen output, and in most cases reduces urinary $\mathrm{N}$ excretion (Mosenthin \& Henkel, 1978; Beames \& Eggum, 1981; Bergner, 1981; Malmlöf \& Håkansson, 1984). The underlying mechanism for both these events has been postulated to be an increased net flux of urea from the circulation into the large intestine, resulting from an increased metabolic activity of the caeco-colonic microflora (Mosenthin \& Henkel, 1978; Beames \& Eggum, 1981; Bergner, 1981). This assumption has been supported by the fact that, in the pig, a high-fibre diet has been associated with a significantly reduced mean portal plasma level of urea (Malmlöf \& Simoes Nunes, 1985). However, no direct evidence that a high-fibre diet induces an important net influx of urea into the large intestine, or the gastrointestinal tract as a whole, has to the author's knowledge hitherto been published. On the contrary, evidence has been presented suggesting that this may not occur (Wolpert et al. 1971; Marty et al. 1976; Forsythe \& Parker, 1985; Wrong et al. 1985). Thus, at present, the possible effects of a high-fibre diet on the fluxes of urea across the gastrointestinal wall of the pig are unclear.

The main objective of the present study was to examine the effect of a high-fibre diet on the net exchange of urea between the gastrointestinal lumen and the circulation. This examination was performed by measuring porto-arterial concentration differences of plasma urea. Since ammonia constitutes the key metabolite of the bacterial hydrolysis of urea, measurements of porto-arterial differences of this substance were also of interest.

\section{MATERIALS AND METHODS}

The effects of a high-fibre (HF) diet, compared with a low-fibre (LF) diet, on porto-arterial plasma concentration differences and plasma levels of urea and ammonia- $\mathrm{N}$ were studied in six female Swedish Landrace $\times$ Yorkshire pigs $(30-52 \mathrm{~kg}$ ). This experiment was conducted 
Table 1. Chemical composition of the experimental diets $(\mathrm{g} / \mathrm{kg})$

\begin{tabular}{ccccc}
\hline Diet & $\begin{array}{c}\text { Crude } \\
\text { protein* }\end{array}$ & $\begin{array}{c}\text { Crude } \\
\text { fibre }\end{array}$ & NDF \\
\hline LF & 174 & 39 & 140 \\
HF & 154 & 95 & 242 \\
\hline
\end{tabular}

NDF, neutral-detergent fibre; LF, low fibre; HF, high fibre.

* $(\mathrm{N} \times 6.25)$.

concomitantly with another experiment (K. Malmlöf, C. Simoes Nunes and J. Örberg, unpublished results) in which the effects of the two diets on porto-arterial plasma concentration differences and arterial plasma levels of immunoreactive insulin, glucose and free amino acids were compared.

To obtain the HF diet, wheat-straw meal was added at $170 \mathrm{~g} / \mathrm{kg}$ to the $\mathrm{LF}$ diet. The wheat-straw meal was obtained by hammer milling the wheat straw over a $3 \mathrm{~mm}$ screen. The LF diet comprised $(\mathrm{g} / \mathrm{kg}) 840$ barley, 120 fish meal, 40 minerals and vitamins. The chemical composition of the two diets is given in Table 1 . The diets were given in isonitrogenous amounts, and approximately the same amount of starch was also given independent of which diet the animals received. Daily rations were calculated to provide the animals with $15.3 \mathrm{~g}$ crude protein $(\mathrm{N} \times 6.25) / \mathrm{kg}$ metabolic weight (live weight $\left.{ }^{0.75}\right)$. The diets were given in the form of an air-dry meal. Water was supplied ad lib via a water nipple placed in the trough.

\section{Surgery}

Before entering the experiment the animals were fitted with permanent blood cannulas introduced into the portal vein and the brachio-cephalic trunc, essentially as described by Rerat et al. (1980). However, medical grade PVC $(2.5 \times 1.7 \mathrm{~mm}$; Noax, Stockholm) and silicone $\left(3.1 \times 1.6 \mathrm{~mm}\right.$, Silastic ${ }^{\mathbb{E}}$; Dow Corning Corp., Midland, USA) catheters were used for the venous and arterial catheters respectively. The portal vein catheter was pushed up along the vessel into the liver and the catheter tip was left approximately at the division of the portal vein into the interlobular veins. Anaesthesia was preceded by an intramuscular injection of $2.5 \mathrm{mg}$ atropine and initiated with an intramuscular injection of azaperone (Stresnil ${ }^{(\mathbb{E})}$ ) at $2 \mathrm{mg} / \mathrm{kg}$ live weight, followed by an intraperitoneal injection of metomidate $\left(\right.$ Hypnodil ${ }^{\mathbb{\mathbb { R }}}$ ) at $10 \mathrm{mg} / \mathrm{kg}$ live weight (Leo, Hälsingborg, Sweden). During operations a suitable level of anaesthesia was maintained by intravenous injections of a penthobarbital sodium salt (Mebumal ${ }^{\circledR} ;$ Aco, Solna, Sweden). At the end of the operations an intravenous injection of heparin (10000-15000 IU) was given to prevent the development of thrombosis.

\section{Experimental procedures and analyses}

After surgery the animals were placed in individual cages and full feed rations were gradually reinstated, with all consuming their full ration within 3-4 d. Meals were given twice daily at 08.00 and 16.00 hours, and lights were on between 07.00 and 19.00 hours.

Three animals were placed directly after surgery on the HF dietary regimen, and three on the LF dietary regimen. At $7 \mathrm{~d}$ post surgery, one series of simultaneously drawn portal and arterial blood samples was obtained from each animal. On the following day, animals which had received the HF diet were given the LF diet and vice versa. After this change of dietary regimen, a time-period of 5 d elapsed before another series of blood samples were collected. Blood samples were drawn during a $16 \mathrm{~h}$ period between 08.00 and 24.00 hours, 
and were drawn every $30 \mathrm{~min}$ during the first $2 \mathrm{~h}$ following each meal, thereafter once every hour. Chilled syringes $\left(4^{\circ}\right)$ were used and the blood was immediately transferred into heparinized tubes which were placed on ice, centrifuged $\left(4^{\circ}\right)$, decanted and frozen $\left(-20^{\circ}\right)$.

In association with blood sampling, urine was continuously collected, via a ballon catheter, into a volumetric flask placed on ice. After $16 \mathrm{~h}$ the volume was registered and a urine sample was frozen $\left(-20^{\circ}\right)$. These samples were later analysed for their urea contents. Chemical analyses of plasma and urine samples were performed on a Technicon AutoAnalyzer. Urea was analysed according to a Technicon standard method (Technicon Instrument Co., 1972) and ammonia-N essentially as described by Imler et al. (1972). Analyses of urea and ammonia-N were performed within $2 \mathrm{~d}$ after sampling.

The crude protein content of feeds was analysed according to the conventional macro-Kjeldahl method. The method described by Robertson \& Van Soest (1981) was employed to determine the neutral-detergent fibre (NDF) content of the feeds.

\section{Calculations and statistics}

The differences between the portal and arterial plasma concentrations of urea and ammonia-N (porto-arterial differences) were calculated individually for each animal and time of sampling. Thus, in the Figures showing the changes with time of porto-arterial differences and the underlying portal and arterial plasma levels, each point represents the mean value of six individual observations with the standard errors of these means represented by bars.

To evaluate the significance of the systematic effect wheat-straw meal appeared to have on portal and arterial levels of urea, the values were subjected to analysis of variance. This analysis was done on the mean urea concentration found among the twenty-one portal and arterial plasma samples obtained from each animal in association with each of the two diets. However, before this was done it was checked whether the order in which the diets were given had any specific effect that had to be taken into account in the final analysis. This was done according to the following model:

$\begin{array}{llcccccc}\text { Source of variation } & \ldots & \text { Order } & \begin{array}{c}\text { Order } \times \\ \text { animal }\end{array} & \text { Diet } & \begin{array}{c}\text { Order } \times \\ \text { diet }\end{array} & \text { Error } & \text { Total } \\ \text { df } \ldots & & 1 & 4 & 1 & 1 & 4 & 11\end{array}$

Since no significant interaction between order and diet was found the subsequent analysis of values could be simplified and took the following form:

$\begin{array}{llcccc}\text { Source of variation } & \ldots & \text { Animal } & \text { Diet } & \text { Error } & \text { Total } \\ \mathrm{df} \quad \ldots & & 5 & 1 & 5 & 11\end{array}$

The same models were used with regard to values of urinary urea excretions and the calculations were executed by the SAS program (Barr et al. 1979).

\section{RESULTS}

Urea

The HF diet was, in comparison with the LF diet, found to produce significantly $(P<0.01)$ lower portal and arterial plasma urea levels (Table 2, Fig. 1). During the $16 \mathrm{~h}$ studied, the total amount of urinary urea excreted was also significantly $(P<0.01)$ lowered by the HF diet (Table 2). Despite the differences in the absolute plasma levels of urea produced by the two diets, the type of diet seemed to have little influence on the dynamics of postprandial changes of plasma urea concentrations. These changes followed a more or less general 
Table 2. Mean portal and arterial plasma urea concentrations and total urinary urea excretion, over $16 \mathrm{~h}(2 \times 8 \mathrm{~h}$ postprandial periods $)$ in six pigs given two consecutive meals of high $(H F)$ and low- $(L F)$ fibre diets at 08.00 and 16.00 hours

(Mean values with their pooled standard errors for six observations)

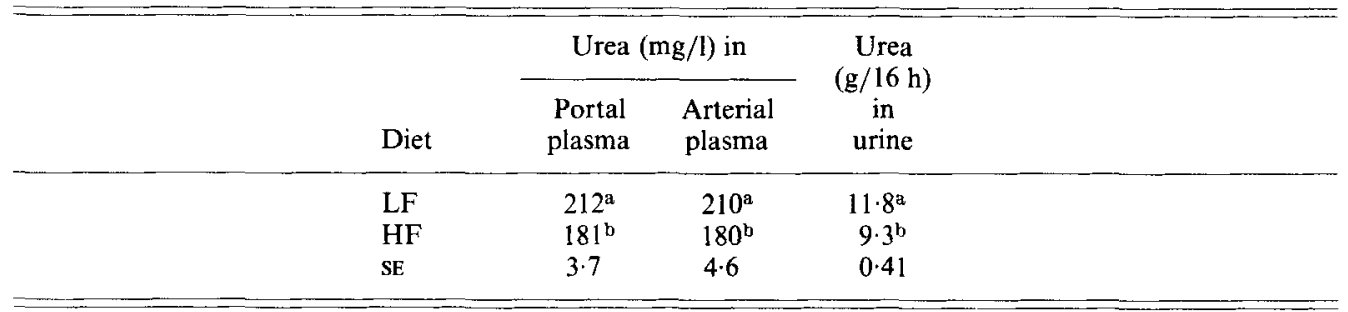

a, b Values within columns with different superscript letters differed significantly $P<0.01$.

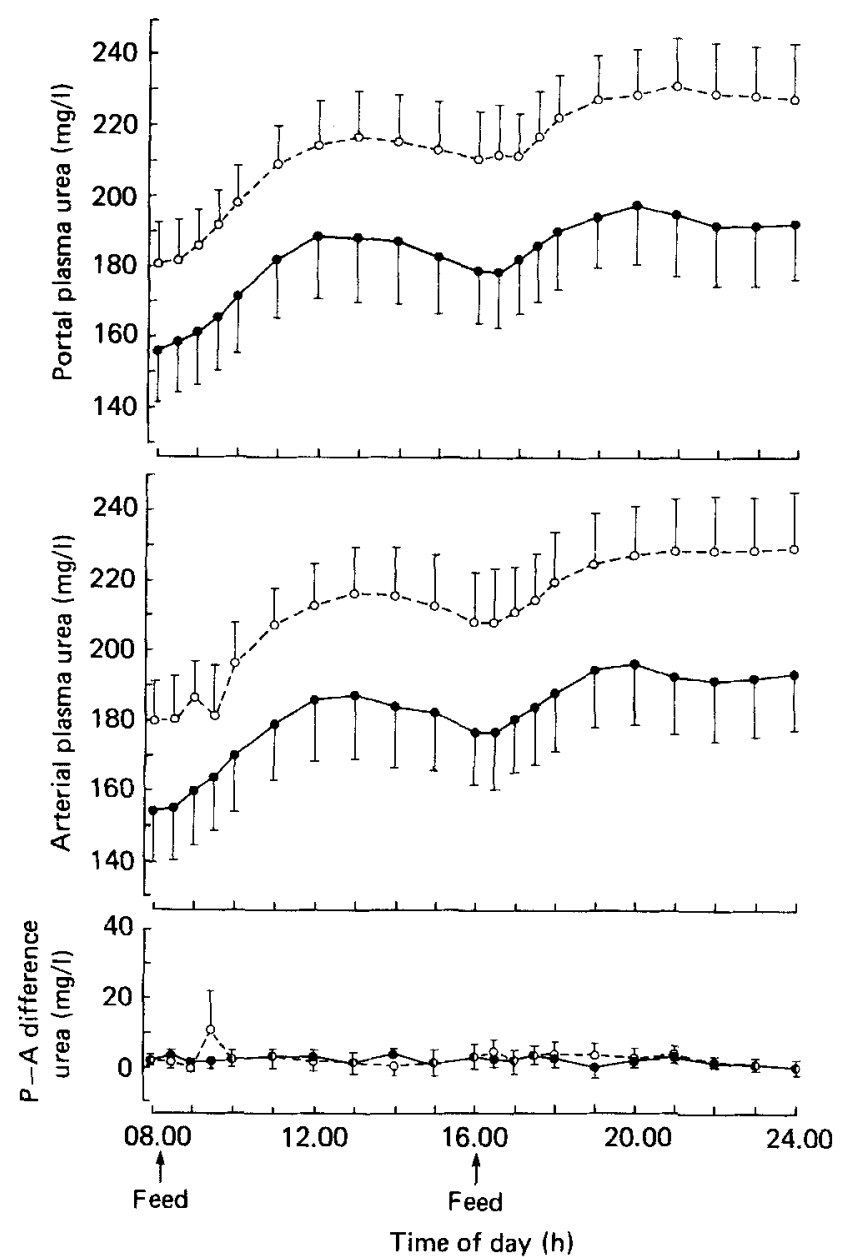

Fig. 1. Changes in porto-arterial (P-A) plasma concentration differences and in portal and arterial plasma levels of urea in six pigs, following two consecutive meals of high-( O) and low-(O---O) fibre diets at 08.00 and 16.00 hours. Points are means with their standard errors represented by vertical bars. 


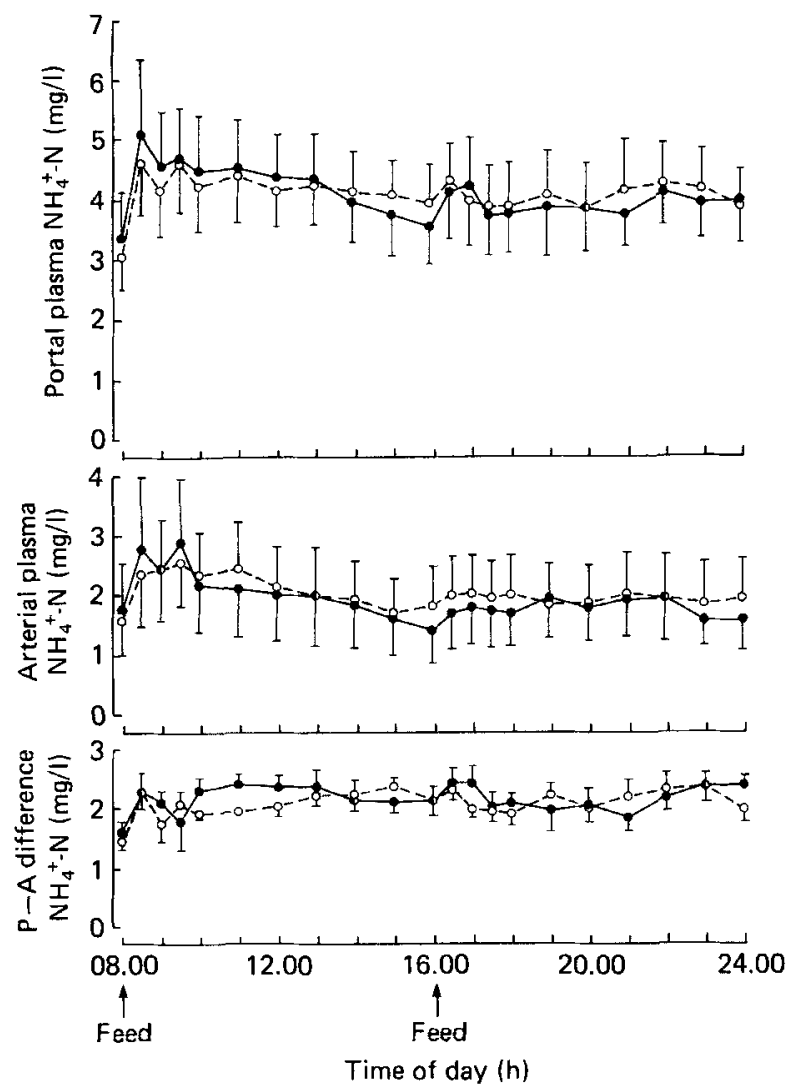

Fig. 2. Changes in porto-arterial (P-A) plasma concentration differences and in portal and arterial plasma levels of ammonia-nitrogen $\left(\mathrm{NH}_{4}{ }^{+}-\mathrm{N}\right)$ in six pigs, following two consecutive meals of high(O--O) and low-(O--O) fibre diets at 08.00 and 16.00 hours. Points are means with their standard errors represented by vertical bars.

diurnal pattern, characterized by increasing plasma urea concentrations up to a point about $5 \mathrm{~h}$ following the 08.00 hours meal. Thereafter the plasma urea concentrations started to decline. This decline was interrupted by the 16.00 hours meal, which caused plasma urea concentrations to rise again. However, in the postprandial period following the 16.00 hours meal, no steady decline in plasma urea levels, similar to that seen in the late phase of the absorptive period following the 08.00 hours meal, was observed. On the contrary, relatively high plasma urea concentrations were maintained throughout this period (Fig. 1).

The two diets had very similar effects on the porto-arterial urea differences (Fig. 1). Thus, throughout the $16 \mathrm{~h}$ studied both diets seemed to induce porto-arterial urea difference values which were close to zero and in no instance clearly negative.

\section{Ammonia- $N$}

No significant differences between the HF and LF diets were found in the effect on porto-arterial differences and plasma levels of ammonia-N. After the rapid initial rise that followed the 08.00 hours meal, these variables remained at a fairly constant level throughout the $16 \mathrm{~h}$ studied (Fig. 2). 


\section{DISCUSSION}

The results obtained with regard to porto-arterial differences of the variables are discussed, based on the assumption that portal blood flow is not differently affected by the two diets. A significant deviation from this basic assumption may change the validity of some of the conclusions made.

A depressing effect of a high-fibre diet on plasma urea in portal blood, similar to that observed previously by Malmlöf \& Simoes Nunes (1985), was confirmed by the results obtained with the HF diet in the present study. However, the lower portal plasma urea levels that were produced by the HF diet could not be explained by a greater net flux of plasma urea from the circulation into the large intestine or any other part of the gastrointestinal tract, since arterial plasma urea levels appeared to be equally depressed by the HF diet, as were portal levels. In consequence, porto-arterial urea differences were in general not differently affected by the two diets. It appears that in spite of an increased supply of fermentable carbohydrates, provided by the host's ingestion of the HF diet, the caecocolonic microflora did not increase its assimilation of blood plasma urea. Accordingly a substantial body of, more or less, firm evidence has been accumulated from experiments in man (Wolpert et al. 1971; Wrong et al. 1985) and in rabbits (Marty et al. 1976; Forsythe \& Parker, 1985) in support of the conclusion that the caeco-colonic microflora have no, or limited, direct access to the blood urea pool.

In a previous study (Malmlöf \& Håkansson, 1984), it was found that a high-fibre diet, in comparison with a low-fibre diet, increased $\mathrm{N}$ retention. These high- and low-fibre diets were, respectively, almost identical to the HF and LF diets used in the present study. An increased $\mathrm{N}$ retention, i.e. protein deposition, would depress the plasma urea concentration and urinary urea excretion. However, this could still not explain the relative shift in $\mathbf{N}$ excretion routes, from urine to faeces, that were also found to be associated with the high-fibre diet used by Malmlöf \& Håkansson (1984).

As was found in the parallel study (K. Malmlöf, C. Simoes Nunes and J. Örberg, unpublished results), the HF diet seemed to depress the mean uptake of free amino acids from the small intestine over the $16 \mathrm{~h}$ studied. This was probably due to an increased ileal output of endogenous amino acids, contained in gastrointestinal secretions of various kinds (Sauer et al. 1977). Given this fact, and bearing in mind that the HF diet, in comparison with the LF diet, did not increase the net flux of plasma urea into the gastrointestinal tract, it appears as if the increase in faecal $\mathrm{N}$ excretion in non-ruminant species on a high-fibre diet (Mosenthin \& Henkel, 1978; Cummings et al. 1979; Beames \& Eggum, 1981; Bergner, 1981; Malmlöf \& Håkansson 1984), may be a function of this increased ileal output of more complex nitrogenous matter, followed by its incorporation into large intestinal bacteria. This latter conclusion is supported by the fact that, in the present study, the amount of ammonia escaping from the gastrointestinal tract appeared to be the same, independent of which diet the animals received, as judged by the porto-arterial ammonia- $\mathrm{N}$ differences. The basic assumption made by Mosenthin \& Henkel (1978), Beames \& Eggum (1981) and Bergner (1981), that an increase in the amount of fermentable energy in the large intestine in the form of dietary fibre, will cause the microflora harboured in this compartment to increase its assimilation of $\mathrm{N}$, appears still to be valid. However, it may be concluded that endogenous urea is probably less involved in this, than was previously thought.

The question now arises as to whether an increased ileal output of endogenous $\alpha$-amino-N could be responsible for the depression in plasma urea levels, seen in association with the HF diet in the present study. Sauer et al. (1977) estimated that on average as much as 0.78 of the amino acids recovered at the terminal ileum of pigs on protein-free diets belonged to the non-essential group, and that proline and glycine alone were responsible for 0.54 of 
the total amount of amino acids leaving this part of the gastrointestinal tract. This study (Sauer et al. 1977) was done with diets ranging in crude fibre content from 39 to $108 \mathrm{~g} / \mathrm{kg}$. The predominance of non-essential amino acids contained in endogenous secretions recovered at the terminal ileum is also supported by the work of Zebrowska et al. (1976). Even after ingestion of dietary protein, the abundance of non-essential amino acids in endogenous matter appearing at the terminal ileum seems to persist (Taverner et al. 1981). These authors (Taverner et al. 1981) concluded that this was dependent on the amino acid composition of the mucin protein, secreted by the epithelium of the gastrointestinal tract, which in addition has been found to be relatively resistant to proteolytic enzymes of endogenous origin (Hashimoto et al. 1963). An increased intestinal disposal of non-essential $\alpha$-amino- $\mathrm{N}$ would most probably also decrease hepatic urea production. Such an event could perhaps explain the lower circulating plasma urea levels and urinary urea excretion that were found in the present study when the pigs received the HF diet.

Not only were postprandial porto-arterial urea differences independent of the type of diet the animals received, but appeared to be close to zero and were never found to be clearly negative. These latter observations imply that a net flux of plasma urea directly from the affluent blood into the digestive tract of the pig does not always occur. This is rather surprising, since it could be suspected that plasma urea will directly enter the small intestine up to a critical point, this being when the urea concentration of small intestinal contents approaches the plasma urea concentration (Hecker, 1971). Accordingly, Rerat et al. (1979) reported a small but significantly negative porto-arterial urea differences in normal growing pigs given a semi-purified diet ( $120 \mathrm{~g}$ crude protein $/ \mathrm{kg}$ ) at comparatively low planes of nutrition. The reason as to why this was not found in the present study is not clear. However, one possible cause could be that in the present study the feed was given as an air-dry meal, and not as a paste to which water had been admixed, as was the case in the study of Rerat et al. (1979). Although the pigs always had free access to water via a nipple placed in the trough, and thus could adjust the water content of a feed portion before ingestion, they seemed to prefer to consume their feed in a relatively dry form, followed by drinking. As was found by Corring (1980), a low water admixture in a feed portion dramatically increases salivary secretions, and could thus increase the addition of endogenous urea (Kopstein \& Wrong, 1977) to the ingesta already in the oral cavity. However, since the quantitative aspect of such a process at present is unclear, further studies are warranted to show if variations in water intake in direct association with the ingestion of a meal can also produce different levels of porto-arterial urea differences.

Despite the apparent uncertainty of the underlying mechanism, it may, as mentioned earlier, be assumed that the urea concentration of small intestinal contents in the pig is close to that of plasma. This has been found in the horse (Hecker, 1971). Thus, if a diet can influence significantly the volume of distribution of urea within the small intestine, then perhaps also the plasma urea concentration could be affected. Whether the LF and HF diets used in the present study had different effects on the intralumen volume of distribution of urea is not known. It is therefore uncertain whether events of this kind were involved in producing the quite different plasma urea levels that were associated with the two diets studied in the present work. However, this possibility cannot, at present, be excluded.

The author wishes to acknowledge the excellent technical assistance given by Miss Helena Odquist, Mr B. Pettersson and Mrs Siv Björkgren, who helped with computer processing of data. This work was financially supported by a grant (552/83 D4:3) from the Swedish Council for Forestry and Agricultural Research. 
Barr, A., Goodnight, H. H., Sall, J. P., Blair, W. P. \& Chilko, D. M. (1979). SAS User's Guide. Raleigh, North Carolina, USA: SAS Institute Inc.

Beames, R. M. \& Eggum, B. O. (1981). British Journal of Nutrition 46, 301-313.

Bergner, H. (1981). Pig News and Information 2, 135-140.

Cummings, J. H., Hill, M. J., Bone, E. S., Branch, W. J. \& Jenkins, D. J. A. (1979). American Journal of Clinical Nutrition 32, 2094-2101.

Corring, T. (1980). In Current Concepts of Digestion and Absorption in Pigs, Technical Bulletin no. 3, pp. 136-150 [A. G. Low and I. G. Partridge, editors]. Reading: National Institute for Research in Dairying.

Forsythe, S. J. \& Parker, D. S. (1985). British Journal of Nutrition 53, 183-190.

Hashimoto, Y., Tsuiki, S., Nisizawa, K. \& Pigman, W. (1963). Annals of the New York Academy of Sciences 106, 233-240.

Hecker, J. F. (1971). British Journal of Nutrition 26, 135-145.

Imler, M., Frick, A., Stahl, A., Peter, B. \& Stahl, J. (1972). Clinica Chimica Acta 37, 245-261.

Kopstein, J. \& Wrong, O. M. (1977). Clinical Science and Molecular Medicine 52, 9-17.

Malmlöf, K. \& Håkansson, J. (1984). Swedish Journal of Agricultural Research 14, 53-57.

Malmlöf, K. \& Simoes Nunes, C. (1985). In Digestive Physiology in the Pig, pp. 223-226 [A. Just, H. Jörgensen and J. F. Fernandez, editors]. Copenhagen: National Institute of Animal Science.

Marty, J., Lavarde, M.-A. \& Raynaud, P. (1976). Annales de Biologie Animale, Biochimie et Biophysique 16, 85-95.

Mosenthin, R. \& Henkel, H. (1978). Zeitschrift für Tierphysiologie, Tierernährung und Futtermittelkunde 40, $122-123$.

Rerat, A., Lisoprawski, C., Vaissade, P. \& Vaugelade, P. (1979). Bulletin de I Académie Vétérinaire de France 52, 333-346.

Rerat, A., Vaugelade, P. \& Villiers, P. (1980). In Current Concepts of Digestion and Absorption in Pigs. Technical Bulletin no. 3, pp. 177-214 [A. G. Low and I. G. Partridge, editors]. Reading: National Institute for Research in Dairying.

Robertson, J. B. \& Van Soest, P. J. (1981). In Analysis of Dietary Fiber in Foods, pp. 123-158 [W. P. T. James and $O$. Theander, editors]. New York: Marcel Dekker.

Sauer, W. C., Stothers, S. C. \& Parker, R. J. (1977). Canadian Journal of Animal Science 57, 775-784.

Taverner, M. R., Hume, I. D. \& Farell, D. J. (1981). British Journal of Nutrition 46, 149-158.

Technicon Instruments Co. (1972). Clinical Method no. 01. Tarrytown, New York: Technicon Instruments Co.

Wolpert, E, Philips, S. F. \& Summerskill, W. H. J. (1971). Lancet ii, 1387-1390.

Wrong, O. M., Vince, A. J. \& Waterlow, J. C. (1985). Clinical Science 68, 193-199.

Zebrowska, T., Simon, O., Münchmeyer, R. \& Bergner, H. (1976). Archiv für Tierernährung 26, 69-82. 